\title{
$\operatorname{TiN}$ コーティング前の Ar ボンバード処理による 珪素鋼板の磁気特性の変化
}

\author{
井口征夫鈴木一弘 小林康宏
}

川崎製鉄株式会社技術研究所

J. Japan Inst. Metals, Vol. 60, No. 2 (1996), pp. 212-217

\section{Variation of Ar Bombardment Prior to TiN Coating on Magnetic Properties of Silicon Steel Sheet}

\author{
Yukio Inokuti, Kazuhiro Suzuki and Yasuhiro Kobayashi \\ Research Laboratories, Kawasaki Steel Corp., Kawasaki-cho, Chuou-ku, Chiba 260
}

\begin{abstract}
In order to clarify the influence of bombardment on the magnetic properties of TiN-coated silicon steel sheet, various bombardment treatments were applied to polished silicon steel sheets prior to TiN coating by the HCD method. The following results were obtained.

(1) With no bombardment or bombardment for a short time prior to TiN coating, the iron loss $W_{17 / 50}$ (W/ $\mathrm{kg}$ ) of TiN-coated silicon steel sheets was dramatically improved by $0.12-0.14 \mathrm{~W} / \mathrm{kg}$. In contrast, bombardment for a long time reduced the rate of improvement as the bombardment time inceased.

(2) The decrease in the rate of improvement of iron loss with increasing bombardment time was attributed to a decreased rate of improvement in hysteresis loss.

(3) In the analysis of elements and three-dimensional analysis of the surface roughness of the polished silicon steel sheet after bombardment, the oxygen content increased with increasing bombardment time, and the roughness of the sheet also increased. The increase in oxygen caused deterioration of the adhesion of the TiN-coating to the silicon steel sheet.

(4) Thin-film X-ray diffraction inspection indicated that a strong peak of (111) of TiN was weakened with increasing bombardment time.
\end{abstract}

(Received September 4, 1995)

Keywords: grain oriented silicon steel sheet, physical vapor deposition, hollow cathode discharge method, TiN film, bombardment, hysteresis loss, eddy current loss, surface roughness, adhesion

\section{I．緒言}

変圧器その他電気機器の鉄芯として使用されている一方向性 珪素鋼板は，エネルギー危機を契機として，低ェネルギー損失 の材料開発が緊急の課題となっている，最近，従来の珪素鋼板 の鉄損の低減方法とは全く異なったPVD あるいはCVDを利 用して，研磨した一方向性珪素鋼板表面に種々のセラミックを 被覆した表面制御技術を用いることによって，一方向性珪素鋼 板の鉄損が従来の値よりも約 $40 \%$ と顕著に低減させることが 可能であることが報告された(1)(2).さらに，この方法では，(1) 高磁束密度，(2)低磁歪特性，(3)高占積率等，現行の珪素鋼板で は全く得られていない優れた特性も示すことが明らかにされ た。

通常 PVD 法を用いて, 基板表面に $\mathrm{TiN}$ 等のセラミックコ ーティングする際に执いては，コーティング前の基板にボンバ ード処理を施すことによってセラミック膜との密着性を確保し
ている.これと同じ方法を珪素鋼板のような機能材料に適用し た場合，研磨処理した珪素鋼板表面がボンバード処理による鋼 板表面の変化で，磁気特性の向上が期待できなくなる可能性が ある。

そこで，本報では，化学研磨により平滑化した一方向性珪素

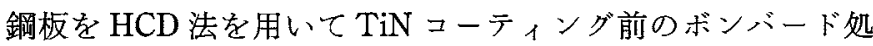
理条件を変光たとさの磁気特性への影響と珪素鋼板の表面状況 調查した。

\section{II. 実 験 方 法}

$0.23 \mathrm{~mm}$ 厚の一方向性珠素鋼板の製品板を用いた。この珪 素鋼の素材成分（以下に各成分を mass\%で表示する）は，C： 0.043 , Si : 3.31, Mn : 0.072, Se : 0.019, Sb : 0.023, Mo : 0.012 で，この製品板を出発素材として用いた．この製品板は 0.23 $\mathrm{mm} \times 30 \mathrm{~mm} \times 300 \mathrm{~mm}$ お よび $0.23 \mathrm{~mm} \times 150 \mathrm{~mm} \times 300 \mathrm{~mm}$

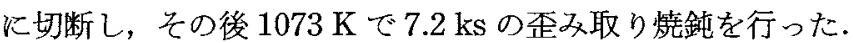


これらの試料サイズは磁気特性湘定の際の SST (Single Sheet Tester, 単板試験器) フレームの大きさが決められているため, この 2 種類の試料を用いた。また，本実験に乱いては，出発 素材の磁束密度が以後の磁気特性に大きな影響を与学るので， 磁束密度の異なる 2 種類の試料 $\left[B_{8}\right.$ が $(\mathrm{A}): 1.93 \mathrm{~T}$ で $W_{17 / 50}$ が 0.88-0.91 W/kg および(B): $1.90 \mathrm{~T} て ゙ W_{17 / 50}$ が 0.89-0.90 W/ $\mathrm{kg}$ の 2 レベル〕製品板から選んで使用した。このとさの磁気 特性は磁化特性と鉄損特性と火より表示されるが，磁化特性は 磁化力 $800 \mathrm{~A} / \mathrm{m}$ に扔ける磁束密度 $\left(B_{8}: T\right)$ により，鉄損特性 は周波数 $50 \mathrm{~Hz}$, 磁束密度 $1.7 \mathrm{~T}$ の乱跨鉄損 $\left(W_{17 / 50}: \mathrm{W} / \mathrm{kg}\right)$ によって表示した。

次に，これらの珪素鍽板の絶縁被膜は溶融 $\mathrm{NaOH}$ 中に浸積 して除去し，さらに $10 \% \mathrm{HCl}(353 \mathrm{~K})$ 中に浸積してフォルステ ライト下地被膜を除去後，鋼板表面を $3 \% \mathrm{HF}$ と $97 \% \mathrm{H}_{2} \mathrm{O}_{2}$ で 化学研磨して表面を平滑にした。

表面研磨後の TiN コーティングは，Fig. 1 の模式図で示す よらなイオンプレーティング装置を用いて行った. Fig. 1 の装 置は一台のイオンプレーティング装置で HCD (Hollow Cathode Discharge) 法と EB(Electron Beam) $+\mathrm{RF}$ (Radio Frequency)法の 2 手法でューティング処理ができるのが特徽である.

さらに，この装置には，Fig. 2 の模式図で示すように珪素鋼 板に $0.5 \sim 20 \mathrm{MPa}$ の引張張力を付加し，かつ鋼板の表・裏面

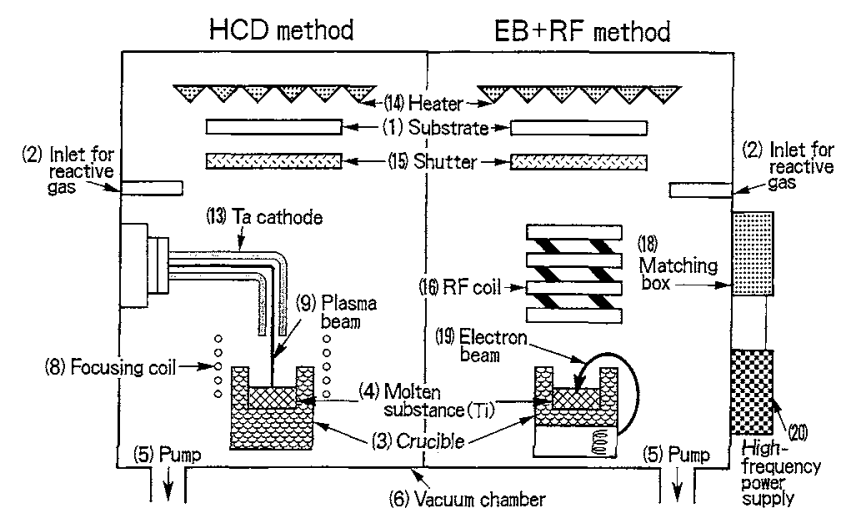

Fig. 1 Schematic diagram of ion plating PVD apparatus used in the $\mathrm{HCD}$ and $\mathrm{EB}+\mathrm{RF}$ methods.

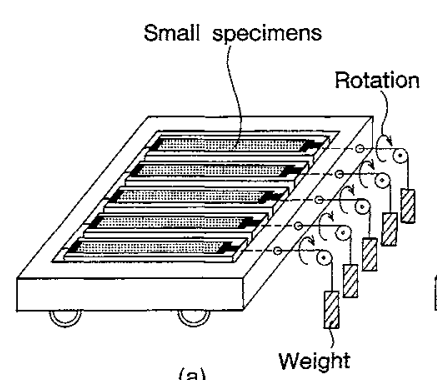

(a)

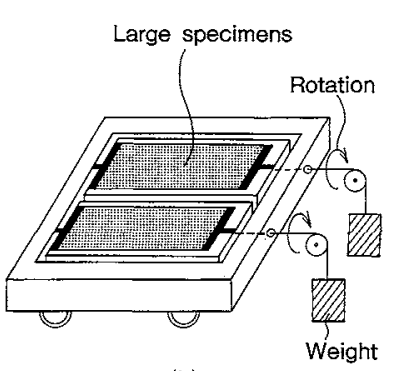

(b)
Fig. 2 Schematic diagram of tensile holders for (a) small and (b) large specimens.
が均一に成膜できるように一軸回転しながらコーティングでき る治具を新たに作成し装着した。特に，この装置に打いては試 料条件を同一にでき，珪素鍽板の磁気特性へのコーティング手 法の影響調查が可能であること，コーティング中の板変形を防 止できること，さらに張力下でのセラミック・コーティング処 理が可能であること，良好な磁気特性を示す適正張力下(3)での コーティングができるのが特徽である、なお，コーティングの 際の珪素鋼板への張力は, Fig. 2 の中の重りの重量を变えるこ とによって行ったが, 通常条件は $3.5 \mathrm{MPa} の$ 張力を付与した.

次に, $\mathrm{TiN}$ ユーティング前のボンバード処理とその後の $\mathrm{TiN}$ ューティングは，次のよらに行った。研磨した珪素鋼板 の試料を Fig. 2 の張力付加装置に装着し, Fig. 1 のイオンプ レーティング装置中に挿入し，装置内を $0.0034 \mathrm{~Pa}$ にをで高真

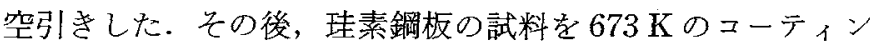
グ温度にまで昇温した後, Ar ガスを装置に導入し, 操作圷力： $9.8 \mathrm{~Pa}$ ，電压 : $360 \mathrm{~V}$ ，電流 : $2.4 \mathrm{~A}$ で $0 \sim 6.0 \mathrm{ks}$ の間，珪素鋼 板表面にボンバード前処理を行った。 その後，HCD 法を用い

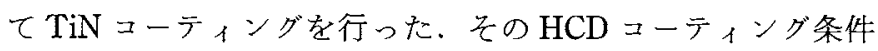
は, 投入パワー: $20 \mathrm{~kW}$, 真空度 : $0.093 \mathrm{~Pa}$, バイアス電圧 :

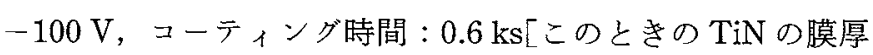
は, 約 $1.0 \mu \mathrm{m}$ 厚で Alpha-step 200 (Tencor instrument(林)を 用いて測定した.]で行った。

$\mathrm{TiN}$ ューティング後の珪素鋼板の試料は, 磁束密度 $B_{8}(\mathrm{~T})$ と鉄損 $W_{17 / 50}(\mathrm{~W} / \mathrm{kg})$ を測定した。また，一部の試料は，周波 数 $50 \mathrm{~Hz}$, 磁束密度 $1.7 \mathrm{~T}$ でのヒステリシス損 $W h_{17 / 50}(\mathrm{~W} /$ $\mathrm{kg})$ の值を测定し，そのとさの珮電流損 $W e_{17 / 50}(\mathrm{~W} / \mathrm{kg})(=W$ 一Wh)の值す求めた. ボンバード処理後の珪素鋼板の一部の 試料は，電界放出形電子顕微鏡 (Hitachi, S-4100) の三次元形状 解析装置(形式: RD-500)を用いて, 加速電圧 : $5 \mathrm{kV}$, 電流: $1.0 \mathrm{nA}$ でボンバード処理による珪素鋼板の表面の粗さを観察 した。また，ボンバード処理後の珪素鋼板の一部の試料は， EPMA[島津製作所㑛，EPMA-8705]を用いて，加速電王： $12 \mathrm{kV}$ ，加速電流 : $50 \mathrm{nA}$ で，表面の元素分析を行った. さら に, TiN 被覆珪素鋼板の磁気特珄測定後の一部の試料は, TiN 膜と珪素鋼板との密着珄を調査するため, 直径 5,10 和よ び $20 \mathrm{~mm}$ の円柱上で TiN 被覆珪素鋼板の $180^{\circ}$ 曲げ試験を行っ てTiNの剝離状態を調查した。TiN膜のX線回折は薄膜 X 線回折装置 (Rigaku, RU-300)を用いて，加速電王：55kV，電 流: $250 \mathrm{~mA}, \mathrm{Cu}$ ターゲットの条件で行った.

\section{III. 実 験 結 果}

Fig. 3 は，磁束密度の異なる二種類の一方向性珪素鋼板 [(A) $\square: B_{8}=1.930 \mathrm{~T}, W_{17 / 50}=0.88 \mathrm{~W} / \mathrm{kg}$ および $(\mathrm{B}) \bigcirc: B_{8}=$ $\left.1.901 \mathrm{~T}, W_{17 / 50}=0.90 \mathrm{~W} / \mathrm{kg}\right]$ 化学研磨した後, Fig. 2(a)の 張力装置を用いて，ボンバード処理を $0,0.6 \mathrm{ks}, 1.8 \mathrm{ks}$ および $6.0 \mathrm{ks}$ 行った後 TiN ューティングを施したときの磁束密度 $B_{8}$ (T) と鉄損 $W_{17 / 50}(\mathrm{~W} / \mathrm{kg})$ の変化をなとめて示したるのである. 

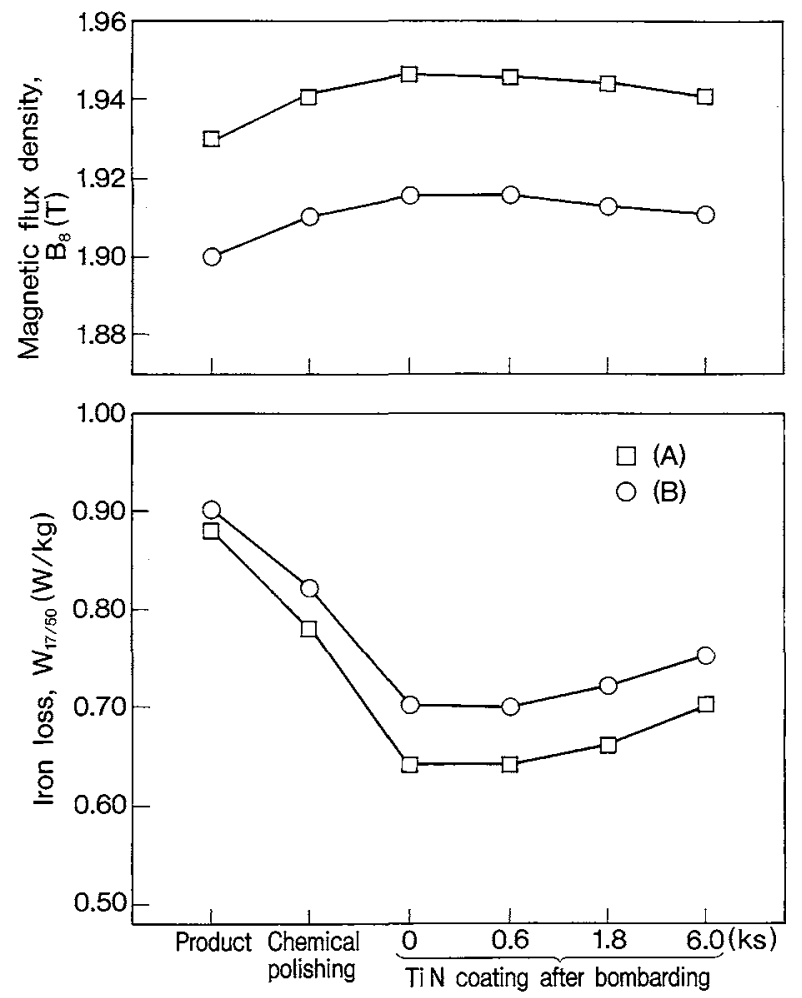

Fig. 3 Variations in magnetic flux density $B_{8}(\mathrm{~T})$ and iron loss $W_{17 / 50}(\mathrm{~W} / \mathrm{kg})$ in each process from original silicon steel product with various bombardment times prior to TiN coating.

な特，図中の各点はFig. 2(a)の張力装置の模式図で示した 5 枚の珪素鋼板試料の平均の磁気特珄值を示したものである.

Fig. 3から明らかな上うに, 被膜除去後の化学研磨において， $B_{8}(\mathrm{~T})$ は 0.009-0.011 T 向上, $W_{17 / 50}(\mathrm{~W} / \mathrm{kg})$ は0.08-0.10 W/

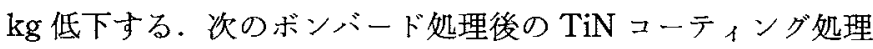
に打いては, $B_{8}(\mathrm{~T})$ が0.001-0.005 T 向上し, $W_{17 / 50}(\mathrm{~W} / \mathrm{kg})$ が 0.07-0.14 W/ $\mathrm{kg}$ と大幅に低減するが，この鉄損の低減度はボ ンバード処理によって顕著に異なることがわかる．例えば，

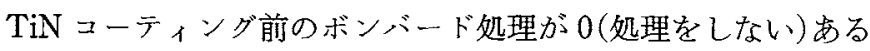
いは $0.6 \mathrm{ks}$ の条件飞执いて, TiN ユーティング後の珪素鋼板 の鉄損の低減の割合は，(A), (B)陚料ともに，0.12-0.14 W/ $\mathrm{kg}$ と顕著であることが注目される。これに対して，1.8 ks 西 るいは $6.0 \mathrm{ks}$ の長時間ボンバード処理を行らと, TiN ューテ ホング処理による鉄損の低減の程度は，0.06-0.12 W/ kg と少 なくなることがわかる. Fig. 3 の珪素鋼板の鉄損の向上度は磁 束密度の高い陚料活ど影著である【製品の $(\mathrm{A})$ 試料の $W_{17 / 50}$ $(\mathrm{W} / \mathrm{kg})$ は $0.90 \mathrm{~W} / \mathrm{kg} \Rightarrow \operatorname{TiN}$ 被覆後は $0.70 \mathrm{~W} / \mathrm{kg},(\mathrm{B})$ 試料の $W_{17 / 50}(\mathrm{~W} / \mathrm{kg})$ は $0.88 \mathrm{~W} / \mathrm{kg} \Rightarrow \mathrm{TiN}$ 被覆後 $0.64 \mathrm{~W} / \mathrm{kg}$ こと, またこれらの各工程の磁気特性の変化は従来の報告した結 果(1)(2) と実験誤差以内で一致している.

Fig. 4 は(B)試料について, 周波数 $50 \mathrm{~Hz}$, 磁束密度 $1.7 \mathrm{~T}$ でのとステリシス損 $W h_{17 / 50}(\mathrm{~W} / \mathrm{kg})$ の值を測定し，そのとき の渦電流損 $W e_{17 / 50}(\mathrm{~W} / \mathrm{kg})(=W-W h)$ の値も求めたときの各

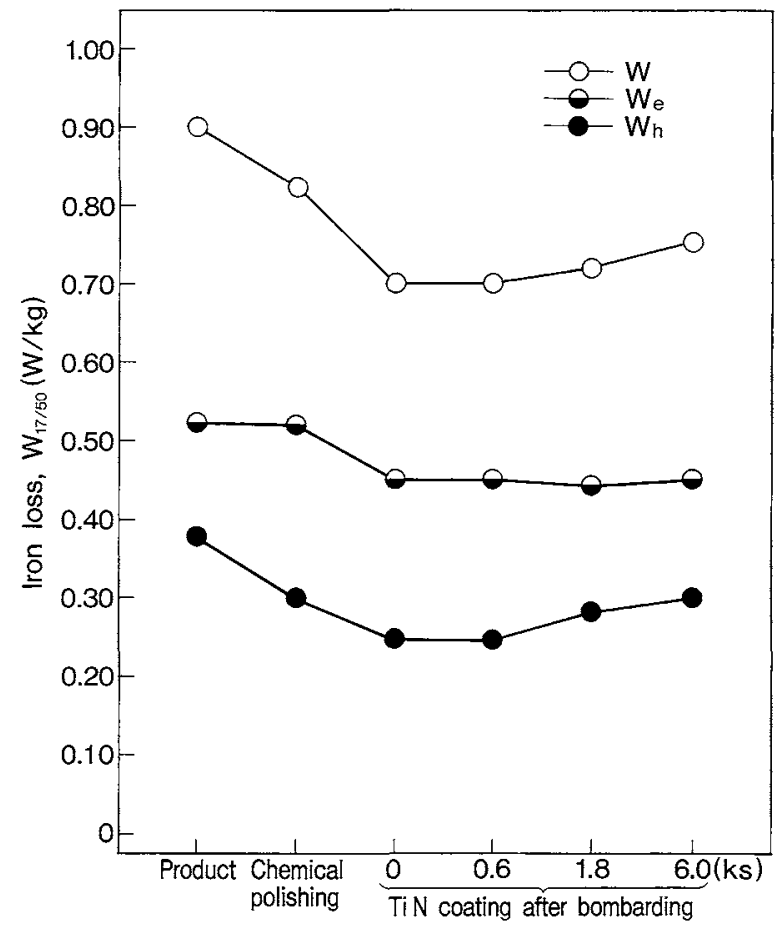

Fig. 4 Variations in iron loss $(W)$, eddy current loss $(W e)$, and hysteresis loss $(W h)$ in each process from original silicon steel product of (B) specimen with various bombardment times prior to TiN coating.

工程に括ける $W, W h$ 就よび We の值の変化の一例をるとめて 示す.Fig. 4 から明らかなよらに，化学研磨したときの鉄損の 低減は汪とんどWhによることがわかる．次の TiN コーティ ングによる顕著な鉄損の低減はWh るが, TiN コーティング前のボンバード処理によって $W h$ と We の低減の割合が異なることが注目される。すなわち，TiN コーティング前のボンバード処理が 0 (処理をしない)あるいは $0.6 \mathrm{ks}$ 条件飞招いて, TiN コーティング後の珪素銅板の鉄 損の向上が最も大きく，その場合のWeの向上の度合いが Whよりも若干大きい。また， $1.8 \mathrm{ks}$ あるい $6.0 \mathrm{ks}$ の長時

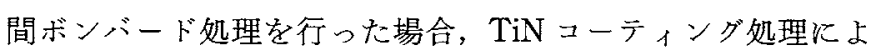
る鉄損の低減の度合いが少なくなるが，それは主にWhの低 減の度合いが少なくなることに起因していることがわかる。

Fig. 5 は，ボンバード処理後の珪素鋼板の表面の粗さを三 次元形状解析装置に上り観察した結果を示したるのである. Fig. 5(a)のボンバード処理しないときの珪素鋼板の表面は, 化学研磨したますの平滑な平面(平均粗さ $R a: 0.018 \mu$ )を示す が，(b)のボンパード処理が $0.6 \mathrm{ks}$ の場合にはボンバード処理 による鋼板表面の凹凸が若干観察される，これに対して，(c) のボンバード処理が $1.8 \mathrm{ks}$ の場合, さらに(d)の $6.0 \mathrm{ks}$ の場合 には，ボンバードによる鋼板表面の凹凸が影著であることが注 目される。

Fig. 6 は，ボンバード処理後の珪素鋼板の表面をEPMA K よる0分析した結果を示すが，ボンバード処理時間が長くな 
(a) Chemical polishing $[\operatorname{Ra}(a v):. 0.008 \mu \mathrm{m}]$

(b) Bombarding for $0.6 \mathrm{ks}$ [Ra(av.): $0.015 \mu \mathrm{m}]$

(c) Bombarding for $1.8 \mathrm{ks}$ [Ra(av. ): $0.0198 \mu \mathrm{m}]$

(d) Bombarding for $6.0 \mathrm{ks}$ $[\operatorname{Ra}(a v):. 0.0319 \mu \mathrm{m}]$

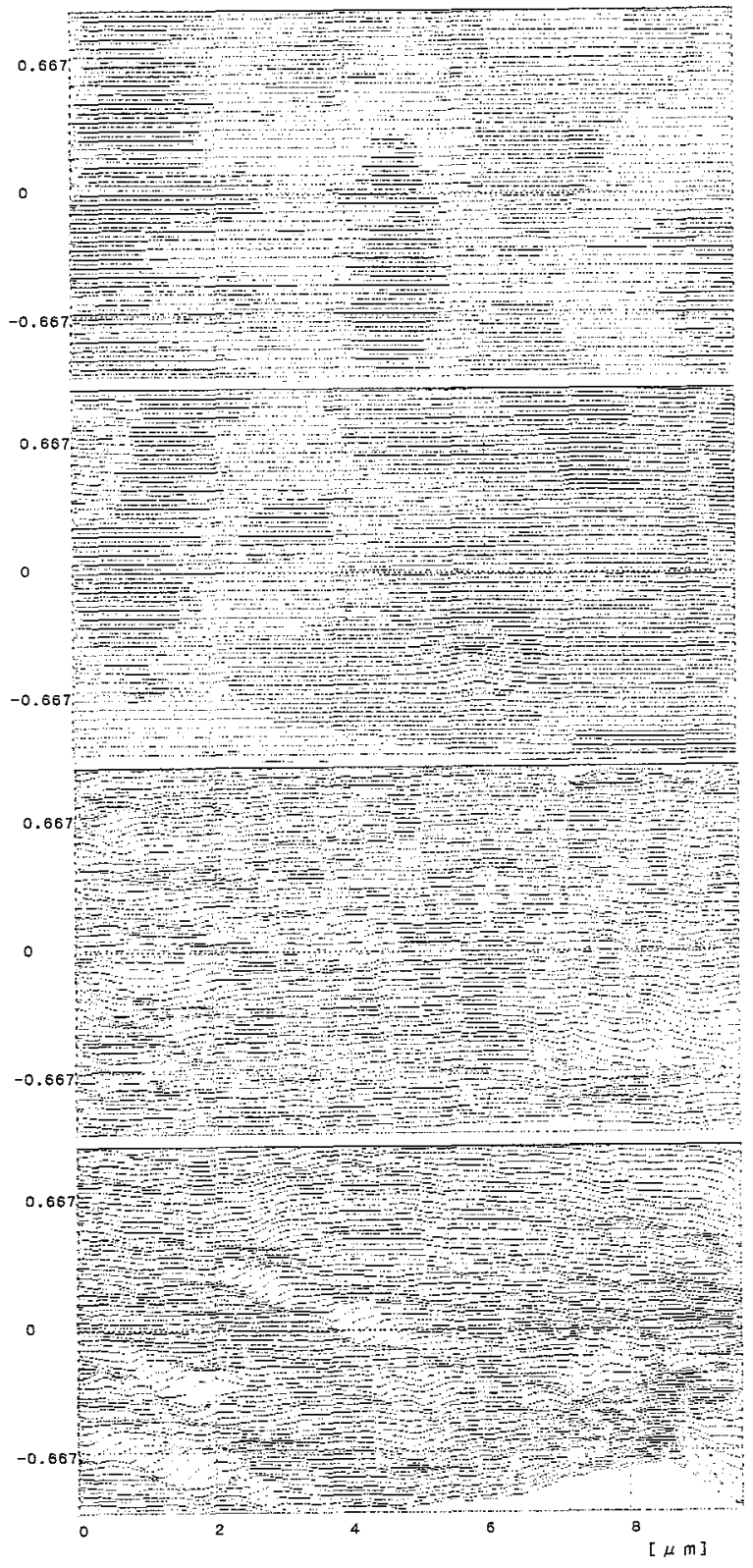

Fig. 5 Three dimensional analysis of surface roughness of silicon steel sheet after bombardment.

るにつれて，鋼板表面にOが多くなることが注目される。こ の他， $\mathrm{Fe}, \mathrm{Si}, \mathrm{S}, \mathrm{C}, \mathrm{N}$ 等について同様の元素を行ったが，実験 誤差の範囲で同じで每った。

Table 1 は, ボンバード処理後の TiNューティングしたと きの TiN 膜と珪素鋼板との㕷離状況を調査した結果をるとめ て示す． $\mathrm{TiN}$ 被覆一方向性珪素鋼板の場合 $\phi 20 \mathrm{~mm}$ の条件下 では全く娳離がなくすべての条件において良好で，珪素鋼板と の密着性火優れている。しかし, 剝離が $\phi 5 \mathrm{~mm}$ や $\phi 10 \mathrm{~mm}$ の 条件下に执いて, ボンバード処理時間が長い場合に叔いて珪素 鋼板の密着性が悪くなった.

Fig. 7 は，TiN 膜の薄膜 X 線回折結果を示すが，ボンバー
ドをしない(a)の試料では，TiN の(111)のみのピークが検出 される。これに対して，ボンバード処理を行った(c)の試料は, TiNの (111) ピーク強度が弱くなり，代わって(200)扣よび (220) ピークが検出されるようになり，さらにボンバード処理 を長時間行った(d)の試料では，この傾向が助長され TiN のピ ークはランダム化することが注目される。

\section{N. 考察}

プラズマコーティングにより基板表面上にセラミックをコー ティングする際には, 基板との密着性を確保するため, 基板表 


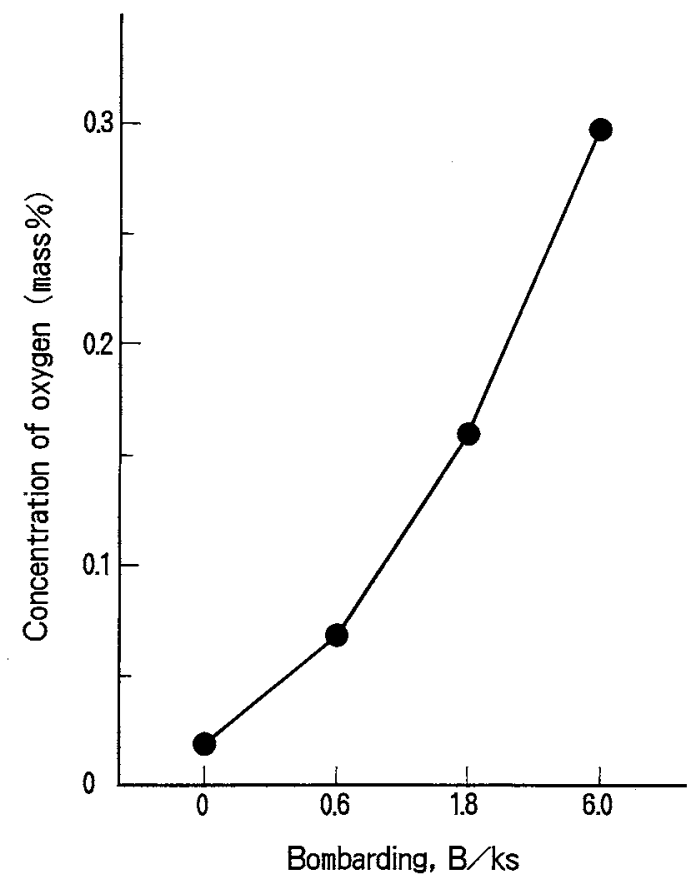

Fig. 6 EPMA oxygen analysis of surface of silicon steel sheet after bombardment.

Table 1 Adhesion between TiN films and silicon steel sheet after bombardment.

\begin{tabular}{c|c|c|c}
\hline & $\begin{array}{c}\text { (a) No } \\
\text { bombarding }\end{array}$ & $\begin{array}{c}\text { (b) Bombarding } \\
\text { for } 0.6 \mathrm{ks}\end{array}$ & $\begin{array}{c}\text { (c) Bombarding } \\
\text { for } 6.0 \mathrm{ks}\end{array}$ \\
\hline$\phi 5 \mathrm{~mm}$ & $\bigcirc$ & $\triangle$ & $\times$ \\
\hline$\phi 10 \mathrm{~mm}$ & $\bigcirc$ & $\bigcirc$ & $\triangle$ \\
\hline$\phi 20 \mathrm{~mm}$ & $\bigcirc$ & $\bigcirc$ & $\bigcirc$ \\
\hline
\end{tabular}

$\bigcirc$ No peel off, $\triangle$ Slightly peel off, $x$ Peel off

面を超音波洗浄等を行って不純物を完全に除去したあと，さら にプラズマコーティング前の基板沃ンバード処理を施す方法 が一般的に採用されている。 これらのプラズマコーティングの 䚾とんどは，耐磨耗性，装飾性，耐食性の改善のために基板之 セラミック膜の密着性のみに重点が执かれていた。しかしなが ら，本実験の珪素鋼板の上らな機能材料に抢引る磁気特性の向 上を目的とする場合には，従来と異なったコーティング方法を 採用する必要がある.すなわち, プラズマコーティングによっ て鉄損を大幅，かつ効率的に低減させ上うとするためには，研 磨した珪素鋼板と TiN 膜との密着性の確保に加えて，本実験 の Fig. 4 の鉄損の変化扣よび Figs. 5 扰よび 6 の珪素鋼板の表 面の粗さの三次元形状解析の観察拉よび表面の元素分析から明 らかなように，珪素鋼板表面の不純物を除去し，表面を平滑化 してヒステリシス損を低下させることが基本的に重要性であ る. 本珪素鋼板の実験結果では, 長時間のボンバード処理の TiN コーティングに执いて珪素鋼板のヒステリシス損の改善 そ悪影響を与兄る。そその理由として，長時間のボンバード処理
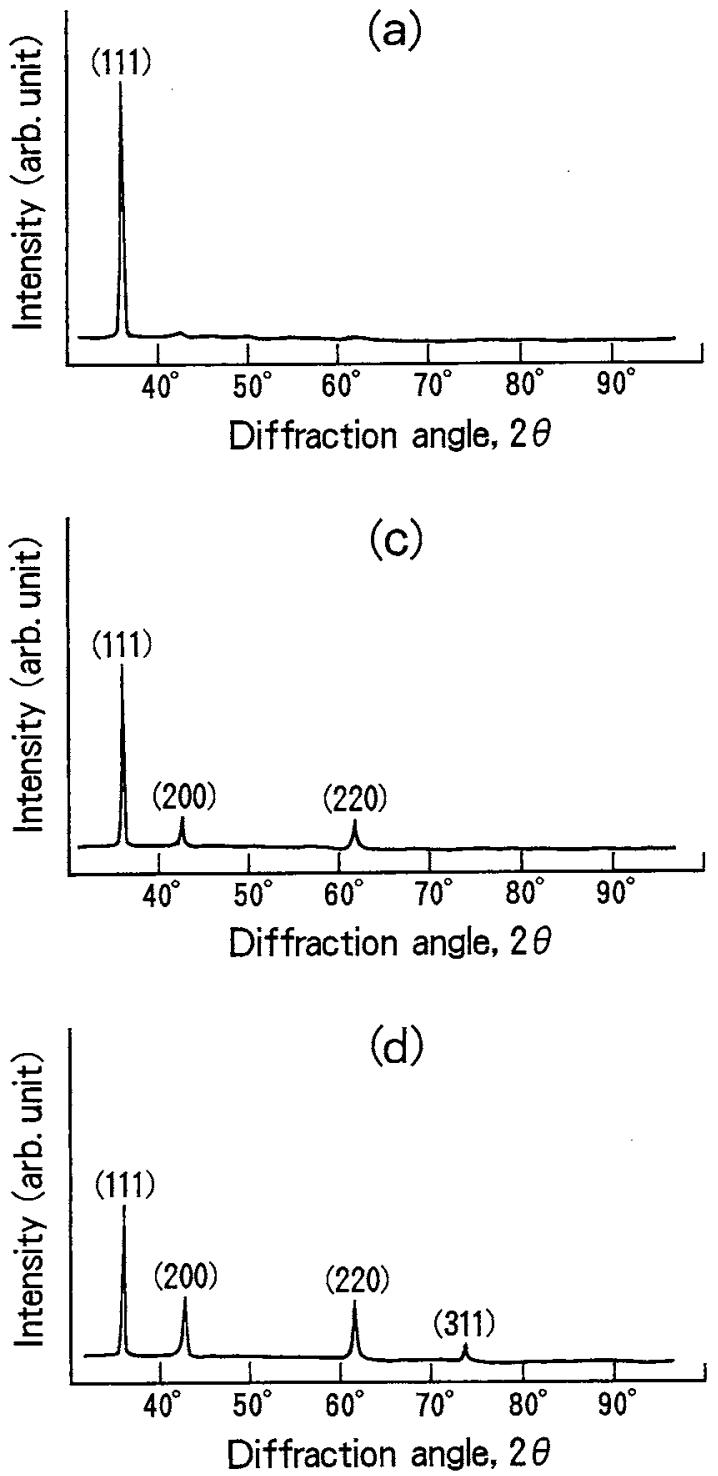

Fig. 7 Schematic diagrams showing X-ray diffraction charts with various bombardment times prior to TiN coating.

を行った場合には，鋼板表面上に0が多く，かつ表面の凹凸 が大きくなることが指摘できる。すなわち，ボンバード処理を 長時間行うと，真空中に存在する 0 が珪素鋼板沉着され， 表面の凹凸も大さくなるためとステリシス損が改善されなくな る.すなわち，基板表面上似 Oが多く存在するようとなると， 例总ば，压延ロール表面上に TiN コーティングを施した場合， ロール表面上にOあるい酸化物が存在すると TiN 膜との密

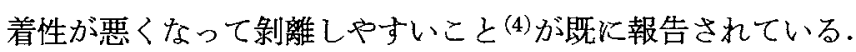

Table 1 の TiN 膜と珠素鋼板との剥離状況を調查した結果か らも，この結果と同じ傾向を示していることがわかる.このた め，大表面積を有する鋼板に TiN ューティングの前処理で密 着性の良好な機能材料を得ようとする際には, 上記のバッチの HCD 装置に採用したボンバード前処理では無く他の方法, 例 兄ば，エレクトロンビーム加熱等を用いることにより鋼板表面 
の清浄化 ${ }^{(5)}$ 図る方法が良いと考光られる。

さらに, TiNの(111)ピーク強度は, ボンバード処理によっ て弱められ，その以外の $(200)$ や $(220)$ ピークが検出されるよ らになり，ピークがランダム化するよらになることが注目され る.このために磁気特性の向上が少なくなるとる考兄られる が，主な原因は上記の鋼板表面の凹凸の形成，Oの吸着度の 方が大きいのではないかと考光られる。また，高真空下で，珪 素鋼板の表面酸化を全く無くして密着性を確保した状態にした としても，鋼板表面の凹凸の形成は，本質的にヒステリシス損 の劣化を招くため, 長時間のボンバード処理に代わる方法を使 用した方が良いと考光られる。

\section{V. 結 論}

研磨より平滑化した一方向性珪素鋼板を HCD 法を用いて $\mathrm{TiN}$ コーティング前のボンバード処理条件を変えた場合の磁 気特性への影響を調查した結果，次のことが明らかとなった。

(1) TiNューティング前のボンバード処理は，全く行わな いかあるいは短時間の場合に扔いて，珪素鋼板の鉄損 $W_{17 / 50}$ $(\mathrm{W} / \mathrm{kg})$ は 0.12-0.14 W/kg と顕著に低減するが，長時間のボ ンバード処理では, ボンバード時間の増加とともに鉄損の低減 が小さくなる.

（2）ボンバード処理を長時間行った場合の珠素鋼板の鉄損の 低下度の減少は，ヒステリシス損の低減が小さくなることに起
因している。

(3) ボンバード処理後の珪素鋼板の表面の粗さを三次元形状 解析による観察では，長時間のボンバード処理によって鋼板表 面の O が多く，表面の山凸も大きくなるとともに，珪素鋼板 の密着性が悪くなる.

(4) プラズマコーティングにより TiN 被覆一方向性珪素鋼 板を製造する際には，珪素鋼板表面をできるかぎり平滑化し て，ヒステリシス損を効率的に低減させることが基本的に重要 である。

(5) TiN 膜の薄膜 X 線回折結果では，ボンバードをしない 試料では，TiNの(111)のみのピークが検出される。これに対 して，ボンバード処理を行った試料は，TiNの(111)ピーク強 度が弱くなり，代わって(200)特よび(220) ピークが検出され， さらにボンバード処理を長時間行った試料では，この傾向が助 長され TiNのピークはランダム化する.

\section{文献}

(1) Y. Inokuti, K. Suzuki and Y. Kobayashi: Mat. Trans., 33(1992), 946.

(2) Y. Inokuti, K. Suzuki and Y. Kobayashi: Mat. Trans., 34(1993), 622.

（3）井口征夫, 船橋敏彦, 伊藤 庸 : 特許公開公報昭62-30302号.

（4）和中宏樹, 条村達己, 下村順一, 上田修三, 佐藤 守, 藤井 兼榮: 鉄之鋼, $74(1988), 2177$.

（5）井口征夫, 小林康宏, 鈴木一弘, 鈴木文仁：特許公開公報平238554 号拉よび特許公開公報平2-54753号. 